\title{
"The development of the insurance market of Ukraine amid the global trends in insurance"
}

\begin{tabular}{ll} 
AUTHORS & $\begin{array}{l}\text { Volodymyr Kurylo } \\
\text { Lyudmyla Kurylo } \\
\text { Yaroslav Zhovnirchyk } \\
\text { Yevgen Kartashov } \\
\text { Sergii Sokol }\end{array}$ \\
$\begin{array}{l}\text { Volodymyr Kurylo, Lyudmyla Kurylo, Yaroslav Zhovnirchyk, Yevgen Kartashov } \\
\text { and Sergii Sokol (2017). The development of the insurance market of Ukraine } \\
\text { amid the global trends in insurance. Investment Management and Financial } \\
\text { Innovations, 14(1-1), 211-216. doi:10.21511/imfi.14(1-1).2017.07 }\end{array}$ \\
\hline ARTICLE INFO & http://dx.doi.org/10.21511/imfi.14(1-1).2017.07 \\
\hline DOI & Monday, 08 May 2017 \\
\hline RELEASED ON & Monday, 20 February 2017 \\
\hline RECEIVED ON & Friday, 31 March 2017 \\
\hline ACCEPTED ON & $\begin{array}{l}\text { (co) Er-Ne } \\
\text { This work is licensed under a Creative Commons Attribution-NonCommercial } 4.0 \\
\text { International License }\end{array}$ \\
\hline LICENSE & "Investment Management and Financial Innovations" \\
\hline JOURNAL & $1810-4967$ \\
\hline ISSN PRINT & $1812-9358$ \\
\hline ISSN ONLINE & LLC "Consulting Publishing Company "Business Perspectives" \\
\hline PUBLISHER & LLC "Consulting Publishing Company "Business Perspectives" \\
\hline FOUNDER &
\end{tabular}

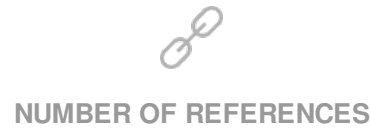

14
NUMBER OF FIGURES

0
NUMBER OF TABLES

7

(C) The author(s) 2023. This publication is an open access article. 


\title{
Volodymyr Kurylo (Ukraine), Lyudmyla Kurylo (Ukraine), Yaroslav Zhovnirchyk (Ukraine),
} Yevgen Kartashov (Ukraine), Sergii Sokol (Ukraine)

\section{The development of the insurance market of Ukraine amid the global trends in insurance}

\begin{abstract}
The insurance market of Ukraine is a part of the global economic environment, which brings together national insurance markets around the world. The paper studies the functioning of the insurance market of Ukraine taking into account the latest trends in the world economy. It notes an extremely small volume of premiums, insufficient coverage of the population and business entities. It is emphasized that the main attention of the experts of the insurance market of Ukraine is focused on its reaction to the annexation of the Crimea and the military conflict in Donbas. It identifies trends, conditions and development factors of the Ukrainian insurance market, as well as its prospects and the role of Ukraine on the global insurance market.
\end{abstract}

Keywords: insurance, insurance market of Ukraine, global insurance market, financial indicators, development trends.

JEL Classifications: G22, G01, G28.

Received on: $20^{\text {th }}$ of February, 2017.

Accepted on: $31^{\text {th }}$ of March, 2017.

\section{Introduction}

Insurance, as an integral function of the state, is a necessary condition for its development. An objective necessity of insurance for the activities of business entities, the state and the population determines its general public nature. As a public authority, the state aims to establish common rules enshrined in law that regulate financial relations in various fields of activities, including insurance, to apply new approaches in public and legal regulation of financial relationships to realize its financial policy.

In Ukraine, one sees a formation of the insurance market, which is based on the principles of entrepreneurship and state supervision over the activity of insurance companies, with the protection of the interests of the state and insurers enshrined in the norms of the finance law. Regulation of the insurance market by the norms of finance law is

(c) Volodymyr Kurylo, Lyudmyla Kurylo, Yaroslav Zhovnirchyk, Yevgen Kartashov, Sergii Sokol, 2017.

Volodymyr Kurylo, Doctor of Legal Sciences, Professor, Honored Lawyer of Ukraine, Head of the Department of Administrative and Financial Law of the National University of Life and Environmental Sciences of Ukraine, Ukraine.

Lyudmyla Kurylo, Doctor of Economics, Professor of the Department of Marketing and Business Management, the National University "Kyiv-Mohyla Academy", Ukraine.

Yaroslav Zhovnirchyk, Doctor of Public Administration, Associate Professor, Head of the Department of Public Administration of the National University of Life and Environmental Sciences of Ukraine, Ukraine. Yevgen Kartashov, Doctor of Public Administration, Associate Professor, Head of the Department of Project Management and General Professional Disciplines, University of Educational Management, Ukraine. Sergii Sokol, Ph.D. in Economics, Associate Professor, Department of Finance and Credit, Kharkiv National University of Construction and Architecture, Ukraine.

This is an Open Access article, distributed under the terms of the Creative Commons Attribution-NonCommercial 4.0 International license, which permits re-use, distribution, and reproduction, provided the materials aren't used for commercial purposes and the original work is properly cited. objectively determined not only by the public and legal nature of insurance coverage, but also by its impact on the cash flows that are redistributed through the system of insurance and which, in this context, determine the role and the place of insurance companies in the economy.

Formation of the national insurance system takes place amid the development of the legal framework for regulating the insurance market and a full renewal of a system of the state insurance supervision. These changes take place in the conditions of globalization and are analyzed in the works of O. Kozmenko (2011, 2012, 2014, 2015), O. Hamankova (2012), V. Bazylevych (2009) and others. In this regard, understanding of the development of insurance on the basis of integration processes in the global economic system is becoming increasingly relevant.

\section{Research of the trends on the global insurance markets and peculiar features of the insurance market of Ukraine}

A significant number of different companies (including insurance and reinsurance companies), institutions and scientists focus on the research of trends in the development of insurance markets, the search for appropriate patterns, clarification of the causes and factors that influence these processes.

According to the report 2016 for on the situation and the prospects of the global insurance markets (Swiss Re Economic Research \& Consulting, 2016), which is annually prepared by the Swiss Re Group, the general situation in the economy, which causes the trends on the insurance markets, is characterized in the following way: the growth in productivity in the advanced economies was very slow; the commodity boom on the eve of the financial crisis contributed to 
strong expectations of growth on the emerging markets, but they were not realized; globalization and trade probably reached their limit and can no longer stimulate economic growth. Regarding the fall in productivity in the advanced economies, it was caused by a number of reasons that are indicated in the report: reduction of the effect from the development and distribution of telecommunications technologies; slow growth in the world trade; reduction of private and public investments in the economy, the growth of the services sector in the general employment of the population.

It should be noted that this is the opinion of the experts of The Swiss Re Group, which specializes in insurance, reinsurance and other activities related to redistribution of risks that it carries out directly or through brokers.

Incidentally, in the previous year they wrote something that to some extent differed from this year's forecast, namely: "The global economy is expected to strengthen moderately next year, in the face of three main headwinds: slower growth in China, lower commodity prices and an imminent rate increase by the US Federal Reserve. Nonetheless, the US, the UK, the Euro area and Japan are all expected to see slightly better growth in 2016. Emerging markets will grow by about 5\%, an improvement on the current $4 \%$ pace" (Swiss Re Economic Research \& Consulting, 2015).

However, the development of insurance markets, including in Ukraine, is taking place among the well-known trends, namely: increased competition; capitalization and concentration of the funds of insurance companies; emergence, introduction and dissemination of the new innovative types of insurance and reinsurance; the use of innovative technologies; continuation and escalation of massive mergers of insurance, banking and financial capital; formation of a unified and standardized international insurance; adaptation of national insurance markets to the well-established principles of international trade, etc.

The world insurance market is a significant segment of the financial market. According to the data published by the Insurance Information Institute (2016) with references to the information of Swiss Re, sigma (Number 4/2015), the amount of premiums on the global insurance market was (Direct premiums written, U.S. \$ millions): 2012 4601329; 2013 - 4593632; 2014 - 4778248, including life insurance: 2012 - 2624993; 2013 2545045; 2014 - 2654549 million US dollars. For risk insurance respectively: 2012 - 2624993; 2013 2545045; 2014 - 2654549 million US dollars.
Therefore, this market not only has a big volume, but it also demonstrates a continuous positive dynamics.

The same Swiss Re, sigma (№ 4/2015) presented data on the volume of insurance premiums in the world's countries, including risk insurance and life insurance (see Table 1). The biggest share on the global insurance market belongs to the US $(26.8 \%)$. China ranks fourth with a market share of around $6.90 \%$ (the GDP of the United States is 17460.0 billion dollars, China's GDP is 17630.0 billion dollars). Therefore, it is possible to talk about the great potential of the insurance market in China, which is demonstrated by all positive trends in the recent years. Occupying the tenth position in the world in terms of insurance premiums is the Netherlands $\left(27^{\text {th }}\right.$ position in terms of GDP).

As for Ukraine, its share of insurance premiums on the global market is extremely low $(0.05 \%)$. There is also a considerable potential for development $\left(48^{\text {th }}\right.$ position in 2014 according to its GDP).

Table 1. Life and non-life insurance premiums, 2014 (Direct premiums written, U.S. \$ millions)

\begin{tabular}{|l|c|c|c|c|}
\hline \multicolumn{1}{|c|}{ Country } & $\begin{array}{c}\text { Nonlife } \\
\text { premiums } \\
(1)\end{array}$ & $\begin{array}{c}\text { Life } \\
\text { premiums }\end{array}$ & $\begin{array}{c}\text { Total } \\
\text { premiums, } \\
\text { amount }\end{array}$ & $\begin{array}{c}\text { Total premiums, } \\
\text { percent of total } \\
\text { world premiums }\end{array}$ \\
\hline $\begin{array}{l}\text { United } \\
\text { States (3), (4) }\end{array}$ & 528221 & 752222 & 1280443 & 26.80 \\
\hline Japan (5), (6) & 371588 & 108174 & 479762 & 10.04 \\
\hline $\begin{array}{l}\text { United } \\
\text { Kingdom (5) }\end{array}$ & 235321 & 115945 & 351266 & 7.35 \\
\hline P.R. China (7) & 176950 & 151490 & 328439 & 6.90 \\
\hline France (8) & 172761 & 97759 & 270520 & 5.66 \\
\hline Germany (7) & 118475 & 136170 & 254644 & 5.33 \\
\hline Italy (9) & 145292 & 49443 & 194735 & 4.08 \\
\hline $\begin{array}{l}\text { South } \\
\text { Korea (6) }\end{array}$ & 101572 & 57943 & 159515 & 3.34 \\
\hline $\begin{array}{l}\text { Canada } \\
\text { (10), (11) }\end{array}$ & 52138 & 73235 & 125373 & 2.62 \\
\hline Netherlands (5) & 21855 & 74100 & 95956 & 2.01 \\
\hline Australia & 31924 & 56151 & 88075 & 1.84 \\
\hline Spain & 38462 & 33012 & 71473 & 1.50 \\
\hline Ukraine & 2068 & 181 & 2249 & 0.05 \\
\hline World & 2123699 & 2654549 & 4778246 & 100 \\
\hline
\end{tabular}

Notes: (1) Before reinsurance transactions, (2) Includes accident and health insurance, (3) Non-life premiums include state funds; life premiums include an estimate of group pension business, (4) Life premiums are estimated, (5) Estimated, (6) April 1, 2014 to March 31, 2015, (7) Provisional, (8) Life premiums are provisional; nonlife premiums are estimated, (9) Nonlife premiums are estimated, (10) Life premiums are net premiums, (11) Life premiums are estimated; nonlife premiums are provisional. 
Table 2. Gross domestic product by country, 2014

\begin{tabular}{|l|c|c|}
\hline \multicolumn{1}{|c|}{ Country } & $\begin{array}{c}\text { Gross domestic product (1) (U.S. \$ } \\
\text { billions) }\end{array}$ & Rank \\
\hline United States & 17460.0 & 2 \\
\hline Japan & 4807.0 & 4 \\
\hline United Kingdom & 2435.0 & 10 \\
\hline P.R. China & 17630.0 & 1 \\
\hline France & 2587.0 & 8 \\
\hline Germany & 3621.0 & 5 \\
\hline Italy & 2066.0 & 12 \\
\hline Canada & 1579.0 & 15 \\
\hline Netherlands & 798.1 & 27 \\
\hline Australia & 1100.0 & 19 \\
\hline Spain & 1534.0 & 16 \\
\hline Ukraine & 373.1 & 48 \\
\hline
\end{tabular}

Notes: (1) Estimate. Based on Purchasing Power Parity calculations, which take into account the relative cost of living and inflation rates of countries. Includes 100 largest countries based on 2014 GDP.

The dynamics of the global markets of risk insurance is presented in the report for 2016 of the Swiss Re Group (Table 3). It should be noted that this dynamics varies considerably in different countries. For example, the United States, Canada, Germany, France, Spain show a steady growth over the past three years. Japan, Australia and, above all, Italy, are significantly reducing their volumes of premiums. But on the whole, the countries with the advanced economy show a positive dynamics, while the dynamics of the countries with the emerging economy is two or three times higher.

Table 3. Real growth of direct premiums written in non-life insurance

\begin{tabular}{|c|l|c|c|c|}
\hline \multirow{2}{*}{ No. } & \multirow{2}{*}{ Country/region } & \multicolumn{3}{|c|}{$\begin{array}{c}\text { Increase/decrease compared to the } \\
\text { previous year, \% }\end{array}$} \\
\cline { 3 - 5 } & & 2014 & 2015 & $2016 \mathrm{E}$ \\
\hline 1 & US & 3.0 & 3.6 & 2.3 \\
\hline 2 & Canada & 1.9 & 4.1 & 0.8 \\
\hline 3 & Japan & 1.2 & 1.3 & -1.0 \\
\hline 4 & Australia & 1.3 & 0.5 & -0.4 \\
\hline 5 & United Kingdom & -1.7 & 1.3 & 1.5 \\
\hline 6 & Germany & 1.8 & 3.3 & 2.5 \\
\hline 7 & France & 0.3 & 1.0 & 0.8 \\
\hline 8 & Italy & -3.0 & -2.9 & -1.8 \\
\hline 9 & Spain & -0.2 & 3.0 & 4.6 \\
\hline & Advanced markets & 1.8 & 2.5 & 1.7 \\
\hline & Emerging markets & 6.4 & 4.9 & 5.3 \\
\hline & World & 2.7 & 3.0 & 2.4 \\
\hline
\end{tabular}

Notes: advanced markets include North America, Western Europe, Israel, Oceania, Japan, Korea, Hong Kong, Singapore, and Taiwan.

Regarding the markets of life insurance (Table 4), it is necessary to mention the United Kingdom, which in 2014 reduced the volume of premiums by $11.9 \%$, but in 2015 returned to the previous positions and even exceeded them. In 2014 Australia experienced growth in the volumes of premiums for life insurance by $26 \%$, which already in 2015 fell by $7.4 \%$ and in 2016 - by $5.7 \%$. On the whole, in terms of life insurance, the countries with the advanced economy demonstrate a positive dynamics (with an annual decrease in growth rates). But in countries with the emerging economy, these rates increase twofold every year.

Table 4. In-force real premium income growth for life insurance

\begin{tabular}{|c|l|c|c|c|}
\hline \multirow{2}{*}{ No. } & \multirow{2}{*}{ Country/region } & \multicolumn{3}{c|}{$\begin{array}{c}\text { Increase/decrease compared to the } \\
\text { previous year, \% }\end{array}$} \\
\cline { 3 - 5 } & & 2014 & 2015 & $2016 \mathrm{E}$ \\
\hline 1 & US & -1.7 & 4.3 & 1.6 \\
\hline 2 & Canada & 7.6 & 3.5 & 3.0 \\
\hline 3 & United Kingdom & -11.9 & 17.6 & 2.2 \\
\hline 4 & Japan & 6.8 & 1.5 & 2.6 \\
\hline 5 & Australia & 26.5 & -7.4 & -5.7 \\
\hline 6 & France & 8.4 & 1.3 & 1.4 \\
\hline 7 & Germany & 2.4 & -2.7 & -2.3 \\
\hline 8 & Italy & 29.5 & 4.0 & -2.1 \\
\hline 9 & Spain & -2.5 & 3.4 & 23.9 \\
\hline 10 & Netherlands & -4.6 & -16.9 & 2.9 \\
\hline & Advanced markets & 4.0 & 3.4 & 2.0 \\
\hline & Emerging markets & 7.8 & 13.2 & 20.1 \\
\hline & World & 4.7 & 5.0 & 5.4 \\
\hline
\end{tabular}

The dynamics of the volumes of reinsurance of the risk types of insurance (Table 5) in the countries with the advanced economy is minor, but positive. For the countries of the emerging markets, it dropped in 2015, and in 2016 it was even negative.

Table 5. Real growth of non-life reinsurance premiums

\begin{tabular}{|c|l|c|c|c|}
\hline \multirow{2}{*}{ No. } & \multirow{2}{*}{ Country/region } & \multicolumn{3}{|c|}{$\begin{array}{c}\text { Increase/decrease compared to the } \\
\text { previous year, \% }\end{array}$} \\
\cline { 3 - 5 } & & 2014 & 2015 & $2016 \mathrm{E}$ \\
\hline 1 & Advanced markets & -1.2 & 0.8 & 1.6 \\
\hline 2 & Emerging markets & 3.7 & 2.9 & -0.7 \\
\hline 3 & World & 0 & 1.4 & 1.0 \\
\hline
\end{tabular}

Swiss Re Group predicts growth in gross premiums for risk insurance in the world in 2017 and 2018 by $10 \%$. Life insurance premiums will grow by $4.8 \%$ and $4.2 \%$ respectively. They will keep growing due to the demand for the savings and investment products, especially in the developing countries. Significant growth rates will be observed for the volumes of insurance in the developing countries, which is caused by the rapid development of online and mobile technologies. It is due to these markets that high growth rates of insurance will be taking place in the world. It is expected that a moderate global economic growth will be boosted by the growth of its insurance segment. There will be a decrease in the value of insurance products in the commercial market segment. There will be a growing demand for insurance against cyber risks. 
We will examine one more study of the insurance market's trends. This is a report for 2015 of the OECD's Insurance and Private Pensions Committee (2016), dedicated to the research of insurance markets in the OECD countries. The authors also note the positive dynamics in the growth of gross premiums in life insurance and this growth is more widespread than in any year since 2010 .

In the context of examining trends on the Ukrainian insurance market of particular interest is the research of the Global Limited Ernst \& Young (EYGM Limited, 2015), although Ukraine is not mentioned in this report. The report notes that in 2015, a macroeconomic environment in most parts of the world shows significant improvement, and the main problems for insurance companies are associated with increasing competition. To effectively overcome such problems, many insurers seek to improve technological solutions, the distribution and servicing of customers, as well as to improve operational efficiency and cost management. Many insurers are investing into digital platforms that strengthen relationships with customers in all geographical regions. They are investing into cloud computing, the development of modeling techniques, improvement of underwriting and risk management.

The report "2015 Global Insurance Market Report" (IAIS, 2015) also emphasizes that the development of insurance depends on global economic factors such as the existence of economic growth, rates of inflation, stability of financial markets, etc. It is noted that in the recent years, there has been a steady increase in insurance premiums and stable profitability in the field of risk insurance. Life insurance experienced a lower increase in premiums. At the same time, the entire insurance sector suffered from a decrease in investments.

Within our study, an interesting question is how different institutions in their reports characterize the state of the Ukrainian insurance market. Unfortunately, because of its low capacity, the Ukrainian insurance market does not deserve their attention. The only company that pays attention to it is Swiss Re Group. It should be noted that the report on the development of insurance markets in 2013 does not mention Ukraine. But in the next year, in 2014, Ukraine drew the attention of experts. Obviously, it was not because of its development rates, but because of the events associated with the annexation of the Crimea and the military conflict in the East. Experts point to an extremely difficult economic situation, indicating that the country's GDP will be declining in 2014 and 2015. Risk insurance in Ukraine is losing its positions and the insurance industry is in a deep recession. Swiss Re Group indicates that "The nonlife business in emerging markets is expected to recover in 2015-2016. The outlook, however, hinges on how the Russia-Ukraine conflict plays out (see special topic on Impact of Russia-Ukraine conflict on Europe). In particular, tough economic conditions in Russia and Ukraine will continue to constrain demand for life lump-sum products".

The report also considers the issues of economic sanctions imposed on Russia in response to the annexation of the Crimea and the escalating conflict in Donbas. It is claimed that the countries of Eastern and Central Europe feel the consequences of sanctions, but they are not significant. "If the situation does not escalate, Europe will mainly be affected through lower trade and tourism. For instance, the EU exports $3.3 \%$ of its goods to Russia and Ukraine, which amounts to $1.1 \%$ of EU gross domestic product (GDP). For Germany, the GDP share is slightly higher at $1.6 \%$. The CEE countries (4.8\% of GDP) are more exposed, particularly the Baltic States (14\%) and the CIS 26 countries $(9.8 \%)$. Overall, a 10\% drop in exports to Russia and Ukraine from Europe would take less than 0.2 percentage points (ppts) off GDP in the EU, 0.5 ppts off GDP in CEE and 0.35 ppts in Central Europe".

In the case of escalation of the military conflict, experts offer three scenarios: 1 (unlikely) - serious problems in the supply of natural gas from Russia via Ukraine, but it will be felt in Europe only in the event of long-term disruptions of gas supply; 2 (very unlikely) - a complete ban on the export of gas to Europe from Russia (which is $30 \%$ of the entire volume of gas consumed by the European countries); 3 (unlikely) - growth of prices for oil and gas in Europe. As you can see, all three scenarios are considered by experts as having little chances to be realized. However, the experts of Swiss Re Group argue that the "Demand for insurance in the conflict countries has declined", which does not correspond to the statistical data that are cited in Ukraine. It is fair to say that in the last three years, the growth of almost all indicators on the insurance market of Ukraine took place only in Ukrainian Hryvnias, but in the US dollars, there was a significant decline in premium volumes (it will be shown below).

In the annual report for 2015, the above-mentioned company does not pay much attention to Ukraine. It cites an extremely difficult economic situation indicating that in this year, there are no prospects to resolve the crisis, which also leads to losses for Europe. A hope is expressed for some improvements in 2016. 
But the report for 2016 states a disappointing fact that the crisis in the economy of Ukraine remains because of the conflict with Russia.

Despite its small capacity, for Ukraine, its insurance market remains one of the most capitalized among other non-bank financial markets.

As of 31.12.2015, the total number of insurance companies was 361, including "life" - 49 companies, "non-life" - 312 companies. It should be noted that as a result of an increased competition on the insurance services market, reduction in the solvency of the population and economic entities in Ukraine, increasing riskiness of business operations (in connection with military operations), the number of insurance companies has decreased in the recent years (in the end of 2013 in Ukraine there were 407 insurance companies, 345 of which carried out "nonlife" insurance).

The main indicators of the insurance market of Ukraine for 2013-2015 are presented in Table 7. The statistics show that in 2014, there was a sharp reduction in the number of concluded contracts (with the exception of contracts of compulsory insurance against transport accidents), namely from 87.3 million to 35.9 million. However, this was not reflected in the volumes of gross insurance premiums, which during the same period declined by about 2 billion UAH. In the next year, there was a sharp increase in the number of contracts, which again provided a small change (positive) in the volume of gross insurance premiums.

Table 6. Basic indicators of the development of the insurance market in Ukraine, UAH

\begin{tabular}{|c|c|c|c|}
\hline \multirow{2}{*}{ Indicator } & \multicolumn{3}{|c|}{ Years } \\
\hline & 2013 & 2014 & 2015 \\
\hline \multicolumn{4}{|c|}{ Number of the concluded insurance contracts, thousand } \\
\hline $\begin{array}{l}\text { Number of contracts with the exception of contracts of compulsory insurance } \\
\text { against transport accidents, including: }\end{array}$ & 87328.5 & 35975.7 & 109106.8 \\
\hline - with insurers-physical persons & 80345.0 & 32699.4 & 106321.2 \\
\hline Number of contracts of compulsory insurance against transport accidents & 97952.0 & 98737.5 & 93322.5 \\
\hline \multicolumn{4}{|c|}{ Insurance activity, mln. UAH } \\
\hline Gross insurance premiums, including: & 28661.9 & 26767.3 & 29736.0 \\
\hline Life insurance & 2476.7 & 2159.8 & 2186.6 \\
\hline Gross insurance payments, including: & 4651.8 & 5065.4 & 8100.5 \\
\hline Life insurance & 149.2 & 239.2 & 491.6 \\
\hline The level of gross payments, $\%$ & $16.2 \%$ & $18.9 \%$ & $27.2 \%$ \\
\hline Net insurance premiums & 21551.4 & 18592.8 & 22354.9 \\
\hline Net insurance payments & 4566.6 & 4893.0 & 7602.8 \\
\hline The level of net payments, $\%$ & $21.2 \%$ & $26.3 \%$ & $34.0 \%$ \\
\hline \multicolumn{4}{|c|}{ Reinsurance, mln. UAH } \\
\hline Paid for reinsurance, including: & 8744.8 & 9704.2 & 9911.3 \\
\hline - reinsurers-residents & 7110.4 & 8173.7 & 7381.1 \\
\hline - reinsurers-nonresidents & 1634.4 & 1530.5 & 2530.2 \\
\hline Payments reimbursed by reinsurers, including: & 486.7 & 640.9 & 1345.8 \\
\hline - reinsurers-residents & 85.2 & 172.4 & 497.7 \\
\hline - reinsurers-nonresidents & 401.5 & 468.5 & 848.1 \\
\hline Premiums received from non-resident reinsurers & 324.0 & 12.9 & 38.1 \\
\hline Payments compensated to non-resident reinsurers & 27.4 & 9.9 & 12.9 \\
\hline \multicolumn{4}{|c|}{ Insurance reserves, mln. UAH } \\
\hline The volume of insurance reserves & 14435.7 & 15828.0 & 18376.3 \\
\hline - life insurance reserves & 3845.8 & 5306.0 & 6889.3 \\
\hline - technical reserves & 10589.9 & 10522.0 & 11487.0 \\
\hline \multicolumn{4}{|c|}{ Insurers' assets and authorized capital, mln. UAH } \\
\hline Total assets of insurers & 66387.5 & 70261.2 & 60729.1 \\
\hline Assets & 37914.0 & 40530.1 & 36418.8 \\
\hline The amount of the paid authorized capitals & 15232.5 & 15120.9 & 14474.8 \\
\hline
\end{tabular}

Notes: As of December 31, the exchange rate of UAH to the US dollar was: $2013-7.99 ; 2014-15.77 ; 2015-23.79$.

As for the concentration of financial resources in insurance companies, it is represented in Table 8. It is interesting that among "life" insurance companies
$42.8 \%$ of insurance premiums are concentrated in three companies, and $99 \%$ of them in twenty companies. 
Table 7. Concentration of the insurance market in Ukraine in 2015

\begin{tabular}{|l|c|c|c|c|c|}
\hline \multirow{2}{*}{ Top } & \multicolumn{2}{|c|}{ "Life" insurance } & \multicolumn{2}{c|}{ "Non-Life" insurance } \\
\cline { 2 - 6 } & $\begin{array}{c}\text { Premium income } \\
\text { (mln. UAH) }\end{array}$ & $\begin{array}{c}\text { Share of the } \\
\text { market, } \%\end{array}$ & $\begin{array}{c}\text { Premium income } \\
\text { (mln. UAH) }\end{array}$ & $\begin{array}{c}\text { Share of the } \\
\text { market, \% }\end{array}$ & $\begin{array}{c}\text { Number of insurance companies, where more than } \\
50 \% \text { of their premiums were received from reinsurers }\end{array}$ \\
\hline Top 3 & 936.1 & 42.8 & 4049.8 & 14.7 & 1 \\
\hline Top 10 & 1921.4 & 87.9 & 10011.2 & 36.3 & 4 \\
\hline Top 20 & 2164.0 & 99.0 & 16613.3 & 60.3 & 7 \\
\hline Top 50 & 2186.6 & 100.0 & 23408.7 & 85.0 & 11 \\
\hline Top 100 & $\mathrm{X}$ & $\mathrm{x}$ & 26472.1 & 96.1 & 13 \\
\hline Top 200 & $\mathrm{X}$ & $\mathrm{x}$ & 27508.6 & 99.9 & 15 \\
\hline Total for the market & 2186.6 & 100.0 & 27549.4 & 100.0 & 22 \\
\hline
\end{tabular}

\section{Conclusions}

All experts agree that in the coming years there will be a further increase in the volumes of insurance and expansion in the range of insurance services in the developing countries. There will be a tendency towards transformation of institutions on the insurance markets and strengthening of relations and cooperation between countries in this area. We expect a growing demand for life insurance and risk insurance. But in some countries (including Ukraine) one can observe (and this trend will continue) the outflow of foreign capital from insurance and the withdrawal of foreign companies from the market. In Ukraine this is related to the consequences of the annexation of the Crimea, the military conflict in Donbass and the dire economic situation in the country in general.

\section{References}

1. Bazylevych, V. (2009). Nova paradyhma strakhuvaniia v umovakh hlobalizatsii. Visnyk Kyivskoho natsionalnoho universytetu im. T. Schevchenka, 186-195.

2. Global Insurance Market Report (GIMAR). (2015). International Association of Insurance Supervisors (IAIS). Retrieved from www.iaisweb.org

3. Global Insurance Market Trends. (2015). OECD Insurance and Private Pensions Committee, 48 p. Retrieved from https://www.oecd.org/daf/fin/insurance/Global-Insurance-Market-Trends-2015.pdf

4. Global insurance outlook. EYGM Limited. (2015). Retrieved from http://www.ey.com/Publication/ vwLUAssets/ey-2015-global-insurance-outlook/\$FILE/ey-2015-global-insurance-outlook.pdf

5. Hamankova, O., Khlivnyi, V. (2012). Strakhovyi rynok u hlobalnomu strakhovomu prostori. Finansy Ukrainy, 5, 58-67.

6. International Insurance Fact Book. (2016). Insurance Information Institute. Retrieved from http://www.iii.org/ sites/default/files/docs/pdf/international_insurance_factbook_2016.pdf

7. Kozmenko, O., Abramitova, D. (2015). The methodical approach to the establishment of interdependencies in the development of insurance and tourism markets. Problems and Perspectives in Management, 13(1), 113-120. Retreived from http://businessperspectives.org/journals/problems-and-perspectives-in-management/issue-47/themethodical-approach-to-the-establishment-of-interdependencies-in-the-development-of-insurance-and-tourismmarkets

8. Kozmenko, O., Lysenko, V. (2014). Contribution of insurance companies to the development of the world health supermarket. Innovative Marketing, 10(3), 6-13. Retreived from http://businessperspectives.org/ journals/innovative-marketing/issue-139/contribution-of-insurance-companies-to-the-development-of-the-worldhealth-supermarket

9. Kozmenko, O. V. et al. (2012). Novi vektory rozvytku strakhovoho rynku Ukrainy. Sumy: Universytetska knyha, $316 \mathrm{~s}$.

10. Kozmenko, O. V. et al. (2011). Strakhovyi i perestrakhovyi rynky v epokhu hlobalizatsii. Sumy, 388 s.

11. Sait Natsionalnoi komisii, scho zdiisnuje derzhavne rehuliuvannia u sferi rynkiv finansovykh posluh. Retrieved from https://nfp.gov.ua/content/informaciya-pro-stan-i-rozvitok.html

12. Swiss Re Economic Research\&Consulting. Global insurance review 2015 and outlook 2016/17. Retrieved from http://www.swissre.com/library/Global_insurance_review_2016_and_outlook_201718.html

13. Swiss Re Economic Research\&Consulting. Global insurance review 2016 and outlook 2017/18. Retrieved from http://www.swissre.com/reinsurance/insurers/Global_insurance_review_2015_and_outlook_in_2016_17.html

14. World Insurance Report. (2016). Retrieved from https://www.worldinsurancereport.com/ 